\title{
ВИМОГИ ДО ОФОРМЛЕННЯ РУКОПИСІВ У ВІСНИКУ КИЇВСЬКОГО НАЦІОНАЛЬНОГО ЛІНГВІСТИЧНОГО УНІВЕРСИТЕТУ. СЕРІЯ ФІЛОЛОГІЯ
}

Редакція Вісника КНЛУ. Серія Філологія приймає до друку матеріали (статті, огляди, рецензії та ін.) від фахівців у галузі лінгвістики за умови, що подані рукописи не публікувалися раніше, відповідають проблематиці Вісника й оформлені відповідно до його вимог. Матеріали мають відображати сучасний стан розробки досліджуваної проблеми й містити нові результати їі вивчення. Теоретичні положення повинні бути аргументовані відповідним ілюстративним матеріалом.

Наукова праця має бути написана на актуальну тему, містити виклад кінцевих або проміжних результатів дослідження, виявляти пріоритети автора в його наукових пошуках.

Редакція проводить внутрішнє та зовнішнє рецензування поданих до друку матеріалів, відхиляє або повертає на доопрацювання статті, які не відповідають вимогам збірника.

Редколегія Вісника КНЛУ. Серія Філологія послідовно дотримується міжнародних видавничих стандартів COPE Code of Conduct, затверджених COP (Committee on Publication Ethics).

Мови публікацій - українська, російська, чеська, польська, англійська, німецька, французька, іспанська, грецька.

Рекомендований обсяг публікацій: обсяг статті - 10-12 сторінок з таблицями, схемами та малюнками; обсяг рецензії - 5-6 сторінок; обсяг хроніки - 3-4 сторінки.

Вимоги до змісту, структури й технічного оформлення наукових статей

Стаття повинна обов'язково містити всі структурні елементи відповідно до п. 3 Постанови ВАК України № 7-05/1 від 15 січня 2003 р.:

- формулювання проблеми та обгрунтування актуальності їі розв'язання;

- аналіз останніх досліджень і публікацій, у яких започатковано розв'язання окресленої проблеми і на які спирається автор (важливо не перерахувати авторів чи їхні публікащії, а саме проаналізувати доробок дослідників, вказати, у чому вони мають рачүію, а в чому-ні; зазначити, які питання залитаються невирішеними);

- мету статті та їі завдання;

- виклад основного матеріалу дослідження з обгрунтуванням здобутих результатів;

- висновки й перспективи подальших досліджень у цьому напрямі;

- список використаних джерел, список лексикографічних джерел $\mathbf{i}$ / або список джерел ілюстративного матеріалу, оформлених стилем АРА.

Структура статті

1. УДК (універсальна десяткова класифікація) - вказувати на початку статті в лівому верхньому кутку першої сторінки.

2. Назва статті (великими літерами по центру, 14 кеглем, напівжирним шрифтом).

3. Прізвище та ініціали автора / співавторів друкувати по центру, 14 кеглем, звичайним шрифтом, великими літерами.

4. Відомості про автора українською мовою: науковий ступінь, звання, місце роботи, електронна адреса. Друкувати через 1 інтервал, звичайним шрифтом, 12 кеглем, вирівняти за правим краєм.

5. Анотація українською мовою та ключові слова (обсяг 800-900 знаків, 5-6 ключових слів), оформлена через 1 інтервал, звичайним шрифтом, 10 кеглем.

6. Відомості про автора англійською мовою: прізвище, ім'я та по батькові, науковий ступінь, звання, місце роботи, електронна адреса. Друкувати через 1 інтервал, звичайним шрифтом, 12 кеглем, вирівняти за правим краєм.

7. Назва статті, анотація та ключові слова англійською мовою. Анотація має стисло відображати зміст статті (1800-2000 знаків) і відповідати вимогам міжнародних наукометричних 
баз. Зокрема, вона повинна містити такі структурні елементи: Introduction, Purpose, Methods, Results, Conclusion. Друкувати через 1 інтервал, звичайним шрифтом, 10 кеглем.

8. Текст статті (без літератури) повинен становити не менше 8 сторінок формату А4 (усі поля - 1,5 см, абзацний відступ - 5 знаків (1,25 см), основний шрифт - 12 кегль, шрифт Times New Roman, інтервал - 1,5).

У тексті статті не використовувати стилі тексту, сторінки не нумерувати, дотримуватися абзацних відступів (5 знаків - 1,25 см).

Цитати й визначення (дефініції) термінів потрібно брати лише в заокруглені лапки (“слово”); розмежовувати знаки дефіса (-) і тире (-), наприклад: “Дискурс-це...”, але “лексико-синтаксичні характеристики”; не замінювати знак апострофа (') чи лапок (“слово”) іншими знаками; фрагменти рукопису, що містять ілюстративний матеріал, друкувати курсивом; світлим шрифтом із підкресленням подавати розкриті у вступній частині позиції: актуальність, мета, завдання та ін.; пропуски в наведених цитатах позначати так: [...]; підрядкові покликання не припустимі. Скорочення на зразок $m$. д., ініціали при прізвищах (напр., I.I. Петренко). указівки на сторінки (c. 34), назви населених пунктів (м. Київ) друкувати через нерозривний відступ (одночасне натискання клавіш Ctrl+Shift+відступ).

Покликання на використану літературу в тексті просимо оформлювати стилем АРА: у круглих дужках потрібно вказувати прізвище автора, рік видання, сторінку, пор.: (Вихованець, 1987, с. 96). Докладніше див. https://www.library.cornell.edu/research/citation/apa.

9. Література (для оформлення списку джерел використовується АРА стиль. Інформація щодо міжнародного стандарту АРА $є$ на сайті НБУВ: http://nbuv.gov.ua/node/929. Також див.: APA Citation Style (https://www.library.cornell.edu/research/citation/apa). Оформити цитування відповідно до стилю АРА можна на сайті онлайнового автоматичного формування посилань: http://www.citationmachine.net/apa/cite-a-book; http://www.bibme.org/apa/book-citation/manual.

Заголовок ЛІТЕРАТУРА друкувати після основного тексту великими літерами ліворуч 3 абзацного відступу. Праці подавати в алфавітному порядку (12 кегль, шрифт звичайний, інтервал - 1,5). За необхідності можна навести ЛЕКСИКОГРАФІЧНІ ДЖЕРЕЛА й ДЖЕРЕЛА ІЛЮСТРАТИВНОГО МАТЕРІАЛУ з продовженням нумерації.

10. REFERENCES (транслітерований латиницею перелік літератури, за винятком англомовних праць, які наводити мовою оригіналу). Для транслітерації латиницею українськоі російськомовних текстів рекомендуємо скористатися програмою з таким режимом доступу: http://litopys.org.ua/links/intrans.htm .

\section{Правила подання матеріалів}

Редакція приймає від авторів зібрані в окремій, підписаній папці документи:

- два роздруковані примірники тексту;

- довідку про автора двома мовами (одна - мовою, якою написано статтю, друга - англійською мовою) на окремому аркуші (ПІБ, науковий ступінь, учене звання, назва навчального закладу чи наукової установи, посада, поштова адреса (з індексом) для надсилання примірника збірника, особистий е-таil автора, номер телефону для зв'язку);

- рецензію або витяг із протоколу засідання кафедри / вченої ради з рекомендацією рукопису до друку.

Електронний варіант статті, довідку про автора, а також відскановані рецензію, витяг 3 протоколу або рецензію наукового керівника надсилати на адресу: knlu-pzs@ukr.net. Усі файли (стаття, довідка про автора, рецензія (витяг) називати англійськими літерами (Article_Radziyevska, Author_Radziyevska Review_Radziyevska, Extract_Radziyevska).

Редакція не повертас авторові (авторам) матеріали, зокрема й не прийняті до друку.

Відповідальний секретар - кандидат філологічних наук

Мінчак Галина Богданівна, тел. моб.: +38 (050) 571-32-78, (068) 554-23-79. 


\section{VISNYK OF KYIV NATIONAL LINGUISTIC UNIVERSITY SERIA PHILOLOGY SUBMISSION GUIDELINES}

Visnyk welcomes papers (including but not limited to research articles, review articles and book reviews) by scholars in the field of linguistics and translation studies. Papers are accepted for publication provided thev have not been published elsewhere, their topics are relevant for Visnyk's research focus and the submitted manuscripts conform to Visnyk's style sheet. The authors are expected to critically appreciate the state of the art of a given problem and report on new findings. Theoretical claims should be supported by evidence from the appropriate data.

A submitted paper should focus on an up-to-date topic, include final or preliminary research results and it should make the author's priorities in the given research area explicit.

Submitted papers are subject to peer review by domestic and international referees. Based on the review results, the papers may be rejected as unsuitable for publication or returned to the authors for revision.

Visnyk's Editorial Board adheres to international publishing standards based on the Code of Conduct developed by COPE (Committee on Publication Ethics).

Language of the paper: Ukrainian, Russian, Czech, Polish, English, German, French, Spanish, or Greek.

Length of the paper: research articles should be 10-12 pages including tables and figures; reviews 5-6 pages; event reports 3-4 pages.

Contents, structure and formatting of research articles

Submitted papers should include the following structural components:

- a clearly stated research problem (and / or research question) and its theoretical or practical relevance to the area of concern;

- a critical overview of the recent literature pertaining to the research topic (please refrain from simply listing works by other authors, instead evaluate their arguments and evidence and point to unresolved issues);

- the goal of the research article and its objectives;

- research results and their discussion;

- conclusions and implications for further research in the field;

- a list of references including cited works (printed and electronic sources), and further sources such as dictionaries and / or literary sources.

\section{Article structure}

1. UDC (Universal Decimal Classification index): in the top left corner of the front page.

2. Title of the article: all capital letters; centre alignment; font size $14 \mathrm{pt}$ in bold.

3. The given name(s) and surname of the author(s): all capital letters; centre alignment; font size 14 pt.

4. Affiliation: centre alignment; font size $14 \mathrm{pt}$ in italics.

5. Abstracts and key words in Ukrainian and English: the abstract in Ukrainian of approximately 800-900 characters and 5-6 keywords (if you do not speak Ukrainian, the Editorial Board will kindly assist you with the abstract in Ukrainian once your paper is accepted for publication) and the abstract (a brief summary of your article) in English of approximately 1800-2000 characters. The abstract in English should comply with academic journal indexing databases and include the author's name, the article title, as well as Introduction, Purpose, Methods, Results, Conclusion. The layout of the abstracts is as follows: indented first line in the paragraph, single line spacing, regular font, font size 10pt. 
8. The main text of the article should not be less than 8 pages in A4 format: all margins are $1.5 \mathrm{~cm}$, the first line in every paragraph is indented by $1.25 \mathrm{~cm}$, the default font is Times New Roman $12 \mathrm{pt}$, spacing is 1.5 lines.

Please refrain from using any text styles, do not add page numbers, make sure that paragraphs have first line indents $(5$ characters $-1.25 \mathrm{~cm})$.

Quotations and word definitions should be enclosed in double quotation marks ("word"). A hyphen (-) must be clearly distinguished from an en dash (-), e.g.: "academic discourse - especially its pedagogical aspects ..." but "lexico-grammatical meaning". Do not replace an apostrophe (') or quotation marks ("word") with other symbols. Linguistic examples should be typed in italics. Topicality, purpose, and objectives of the study should be underlined and included into the introductory part of the paper. Ellipses in quotations are indicated by [...]. Footnotes are not allowed. Shortenings like e.g., initials like I.I. Petrenko, references to pages like p. 34, etc. should be typed as non-breaking spaces (press Ctrl+Shift+Space).

\section{References}

References List and in-text citations are organized in accordance to the APA style (American Psychological Association Style). Information about the usage of the international standard APA is available at NBUV portal: http://nbuv.gov.ua/node/929. Also look at: APA Citation Style (https://www.lidrary.cornell.edu/research/citation/apa). It is possible to format references in accordance with APA at the following online automatic sites http:/www.citationmachine.net/apa/cite-abook; http://www.bibme.org/apa/ book-citation/manual.

The word REFERENCES is typed after the main text in all capital letters; it is aligned on the left and indented by $1.25 \mathrm{~cm}$. The references are listed alphabetically (regular font, size 12pt, spacing 1.5 lines). When needed, a list of DICTIONARIES or LITERARY SOURCES is included with the numbering continued from the previous list, e. g.:

10. REFERENCES (a list of literature transliterated to the Latin script, except for works originally published in the Latin script). To transliterate the Cyrillic script to the Latin script use the software available at: http://litopys.org.ua/links/intrans.htm .

\section{Paper submission}

Please submit to the Editorial Board:

- your paper, which conforms to Visnyk's style sheet;

- information about the author(s) in a separate file including: full given name and surname, academic degree, academic rank, affiliation (postgraduate students should mention their year of study), the position held, and contact information (phone number, postal address and e-mail address);

- your Department's or Academic Council's recommendation to publish your paper.

All files are sent to: knlu-pzs@ukr.net. Each of these files should be named in English: Article_Radziyevska, Author_Radziyevska Review_Radziyevska, Recommendation_Radziyevska

Papers submitted to the Editorial Board, including rejected ones, are not sent back to the authors.

Executive Secretary - Halyna B.Minchak, Candidate of Sciences (Linguistics).

Tel: +38 (050) 571-32-78, (068) 554-23-79. Editorial Board 